\title{
MODERN LEADERSHIP TYPES AND OUTCOMES: THE CASE OF GREEK PUBLIC SECTOR*
}

\author{
Irene Samanta** \\ Athanasios Lamprakis ${ }^{* * *}$
}

Received: 6.7.2017

Preliminary communication

Accepted: 27. 4. 2018

UDC 005.5:159.9>35(495)

DOI https://doi.org/10.30924/mjcmi/2018.23.1.173

\begin{abstract}
The aim of this research is to highlight the characteristics of modern leadership types, under the Multifactor Leadership Theory, i.e. the Transformational, Transactional and Laissezfaire Leadership types. The research objectives focus on distinct effects of these leadership types on both 'followers' (employees') perceived leadership outcomes", namely the "followers' perceived leadership effectiveness" and the "followers' job satisfaction", according to Bass. The research was conducted by a case study in the Greek public procurement sector, with the usage of the Multifactor Leadership Questionnaire
\end{abstract}

\section{INTRODUCTION}

Leadership has been one of the most important variables in interpreting organizational results and the employees' work behaviour. In turn, the classic theories focused either on the characteristics of leaders, on their behaviour, on the environmental
(MLQ). Transformational Leadership was found to strongly and positively determine both the "followers' perceived leadership effectiveness" and "followers' job satisfaction", while the positive impact of Transactional Leadership on these two criteria proved to be less strong, followed by the strongly negative effect of Laissez-faire Leadership. The conclusions drawn can be applied in public sector organizations with high performance standards.

Keywords: Transformational Leadership, Transactional Leadership, Laissez-faire Leadership, Followers' Perceived Leadership Effectiveness, Followers'Job Satisfaction.

factors, or on their interactions with the followers in order to construct interpretations for conduct, efficiency and effectiveness of workers and organizations (Horner, 1997; Van Seters and Field, 1990). Key criteria for this interpretation were the two classic approaches to leadership outlined by the

\footnotetext{
${ }^{*}$ The data for this paper were collected as part of the thesis by Lamprakis Athanasios, in the Department of Business Administration of the Piraeus University of Applied Sciences, under the supervision of Dr. Irene Samanta, for the purpose of obtaining the MSc. in "International Business Management with specialization in International Human Resource Management".

** Irene Samanta, PhD, Assistant Professor, Piraeus University of Applied Sciences, Department of Business Administration, Petrou Ralli \& Thivon 250, Aegaleo 12244, Greece, e-mail:isamanta@puas.gr

*** Athanasios Lamprakis, MSc, Piraeus University of Applied Sciences, Petrou Ralli \& Thivon 250, Aegaleo 12244, Greece, e-mail:lamprakis.than@gmail.com
} 
scholars of Ohio State University and the University of Michigan, namely the "consideration, or employee orientation, or peopleoriented leadership" and the "initiation of structure, or production orientation, or taskoriented leadership" (Armandi et al., 2003; Avolio, 2007; Silva, 2015).

Bass (1985, as cited in Bass, 1990), based on the emerging concepts of charismatic leadership, initiated by House (1977, as cited in House, 1996) and transformational leadership, devised by Burns (1978, as cited in Yammarino and Bass, 1990) established a new leadership model known as Multifactor Leadership Theory which included the Transformational, Transactional and Laissez-faire Leadership types (Bass, 1990; Bass and Avolio, 1990). Subsequently, Bass and Avolio (1992; 1995) initiated a full research questionnaire named the Multifactor Leadership Questionnaire/MLQ in order to measure and evaluate these new types of leadership and their particular characteristics and effects.

It has been proven that "Leadership" is the most strategic component in what is known as "organizational system", made up of various elements, such as structure, objectives, relations, rewards, procedures and organizational policies, always depending on the needs for flexibility created by external factors. Transformational Leadership plays a predominant role in contemporary leadership theory, which surveys confirm to be strongly correlated with the full spectre of organizational results, such as effectiveness, motivation, innovation, work engagement, satisfaction, learning, etc. (James and Ogbonna, 2013; Khan et al., 2012; Podsakoff et al., 1990; 1996). The hypothetical connection between Transformational Leadership and these organizational results is empirically demonstrated by research proving the effect this leadership type practices have on the variables referred to as "Leadership Outcomes" by Bass and Avolio (1992; 1995), namely, the "Followers' Perceived Leadership Effectiveness" and the "Followers' Job Satisfaction".

The clear effect of Transformational Leadership on these dependent variables, as compared to the effects of Transactional and Laissez-faire Leaderships, explains the distinct status of this leadership type and its strong impact on the full range of organizational results. At the same time, this fact forms empirical evidence of the validity of Bass' Multifactor Leadership Theory, as the most comprehensive and reliable model describing modern leadership (Hinkin and Schriesheim, 2008; Judge et al., 2004; Judge and Picollo, 2004; Tejeda et al., 2001). The biggest challenge in this research has been the verification of the implementation of this leadership model in Greek organizational reality, especially the detection of transformational leadership characteristics in Greek public administration, as the first step towards reforming it.

The Greek Public Procurement Sector, which was chosen as the research ground for this case study, is considered a key lever for the development of a transparent and reliable public administration system. The theoretical objective of this research consists of a bibliographical presentation of the concept of leadership and its entailing results, as these are expressed in Bass' Multifactor Leadership Theory. The empirical objective of this research is the detection of these distinct leadership types mentioned in Bass' Multifactor Leadership Theory in the field of Greek Public Procurement Sector and the assessment of the effects that these types have on two certain dependent variables, i.e. the "Followers' Perceived Leadership Effectiveness" and the "Followers' Job Satisfaction", which reflect, respectively, the 
two classic leadership orientations, namely the classic orientations either towards the "task/production" or towards the "people/relations" (Armandi et al., 2003; Avolio, 2007; Silva, 2015).

\section{THEORETICAL REVIEW AND HYPOTHESES}

\subsection{Multifactor Leadership Theory and Modern Leadership Types}

Bass (1990) argued that until his time the traditional leadership theories had focused mainly on the assignment of tasks and their fulfilment by the employees (referred to as "followers" by Bass), in return for possible rewards or sanctions by the leader. This "compromise" version of leadership was limited only to basic "transactions" between leaders and members. Bass identified the need to develop a new leadership model that would be able to encourage and motivate members to go further beyond their personal interests, in search of a greater good for the team and the organization, via the achievement of optimal performance levels. This type of leadership was identified as "Transformational Leadership". It was developed mainly in the 1990 s, but it remains up-to-date as it seems to be the most relevant and modern approach concerning the concept of "leadership" and the outcomes that this concept generates (Bass, 1990; Bass and Avolio, 1990; Kuhnert and Lewis, 1987; Yammarino and Bass, 1990).

\subsubsection{Transformational Leadership}

"Transformational Leadership" motivates and inspires ("transforms") the followers to achieve outcomes beyond the expected ones. It envisages concerns, preoccupations and needs of followers, it changes ("transforms") their perception towards the organizational matters, asking from them to handle old issues in new ways and focusing on team success and not the individual one. "Transformational Leader", taking account of skills and shortcomings of the followers, relates the delegated tasks with objectives and procedures that entail the highest possible efficiency and benefits for the organization (Antonakis, 2001; Antonakis and House, 2014; Bass and Avolio, 1990; Day and Antonakis, 2011).

"Transformational Leadership" boosts motivation, morale and performance of the followers, through a variety of instruments. "Transformational Leaders" correlate personal identity and concept of the individual benefit with the perspective of the collective identity of the organization and the benefit of the team. A Transformational Leader, embodying the role described in this model, inspires and challenges the followers to demonstrate an improved degree of self-reflection on their work and the organization (Antonakis, 2001; Antonakis and House, 2014; Day and Antonakis, 2011; Podsakoff et al., 1990; 1996).

"Transformational Leadership" has been theoretically shaped comprising four essential qualities (factors):

a) Charisma or Idealised Influence which creates and puts forward the vision and the sense of mission, instilling primacy, respect and mutual trust. Transformational leaders act in exquisite and innovative ways, demonstrating attitudes and values that exercise maximum influence on others (followers), in order to seek their self-reflection with these leaders (Antonakis, 2001; Bass, 1990; Bass and Avolio, 1990; Day and Antonakis, 2011).

b) Inspiration or Inspirational Motivation which communicates high expectations, uses symbols focusing on effort and expresses the ultimate purposes by 
simple means. The transformational leader is a bearer of a vision that inspires and motivates others, instilling the idea that they can achieve things beyond the expected ones (Antonakis, 2001; Bass, 1990; Bass and Avolio, 1990; Day and Antonakis, 2011).

c) Intellectual Stimulation which demands intelligence, logic and the prudent decision making in solving problems. The transformational leader indicates to others new ways of thinking, new ways to leverage opportunities, focusing on creativity, development and innovation (Antonakis, 2001; Bass, 1990; Bass and Avolio, 1990; Day and Antonakis, 2011).

d) Individualized Consideration which targets each employee (follower) individually, guiding, advising and empowering him/ her. The transformational leader expresses personal responsibility and functions as a mentor to others. Such leader respects the personality and contribution of every individual to the overall effort and assigns tasks according to aptitudes and interests of each employee (Antonakis, 2001; Bass, 1990; Bass and Avolio, 1990; Day and Antonakis, 2011).

\subsubsection{Transactional Leadership}

Transactional Leadership is a process of "transaction" between the leader and the others (followers/employees/members). It is based on the employees' fulfilment of the contractual obligations arising from their tasks, in return for the leader's care for the supervision of the full process of achieving the objectives and for the reward of those who complied with them. Transactional leaders specify the role and the responsibilities of each worker/employee individually and they also reward, either financially, by a salary increase, or morally, by recognition and promotion, those workers/employees who have achieved their goals (Bass, 1990;
Hinkin and Schriesheim, 2008; James and Ogbonna, 2013).

Unlike transformational leadership, the transactional leaders do not focus on future vision, but they insist on current practices, requesting followers to officially abide by the rules. The transactional leaders are committed to the existing procedures, ignoring the need to develop ideas in order to improve the efficiency and effectiveness of the organization. They focus on personal motives and interests of others instead of the shared interests of the team and the organization (Bass, 1990; Bass and Avolio, 1990; Day and Antonakis, 2011; Kuhnert and Lewis, 1987).

Transactional Leadership refers to the lower needs of people, in Maslow's terms, while Transformational Leadership has to do with the higher ones. However, according to Bass (1990), the two leadership types, despite their differences, are not contradicting each other, but rather act as complementary leader notions, enhancing each other. Clearly, the characteristics of transformational leadership bring better results to the organization, if these elements co-exist with those of the transactional leadership, according to the so-called "augmentation hypothesis" of Bass (Bass, 1990; Bass and Avolio, 1990; Kuhnert and Lewis, 1987).

"Transactional Leadership" has been theoretically shaped comprising three essential qualities (factors):

a) Contingent Reward which includes accepting the exchange of payment in return for the effort, promising to reward good performance and compensating for achievements. Employees who have not succeeded in the expected are "penalised" with sanctions. The whole relationship between leader and followers is ruled by the wellestablished principle of transaction, which is reward in return for good performance and 
the adverse consequences in return for poor performance (Antonakis, 2001; Bass, 1990; Day and Antonakis, 2011).

(b) Management by exception-active presumes that the leader keeps the others constantly guided by him, identifying deviations from the rules and making the best remedial actions (Antonakis, 2001; Bass, 1990; Day and Antonakis, 2011).

c) Management by exception-passive presumes that the leader's intervention only in extreme cases where standards are not respected (essentially a step below the laissezfaire leadership), (Antonakis, 2001; Bass, 1990; Day and Antonakis, 2011).

However, according to Bass (1990) and Avolio et al. (1999), the transformational and transactional leadership types, despite their differences, are not mutually competitive, but they constitute complementary forms of leadership. Both these leadership styles may coexist within the same leader, but at a different degree. Leaders, for example, can exhibit both transformational and transactional features, but they manifest these features in a different amount and intensity, so that one style appears to be more distinct than the other. Empirical studies aiming to test the validity of the Multifactor Leadership Theory by Bass have demonstrated the strong positive correlation that exists between the transformational and transactional leadership types (Antonakis, 2001; Antonakis et al., 2003; Avolio et al., 1999; Day and Antonakis, 2011; James and Ogbonna, 2013; Judge and Piccolo, 2004; Kuhnert and Lewis, 1987; Tejeda et al., 2001).

From the above-mentioned literature review and the empirical studies, the following research hypothesis can be formed:

H1) Transformational Leadership is positively correlated with Transactional Leadership.

\subsubsection{Laissez-faire Leadership}

This type of Leadership constitutes the absent and non-existent leadership which avoids decision-making, does not make use of its power and refuses its responsibilities. The Laissez-faire leaders are not informed of their duties, they do not decide, do not guide and do not intervene in case a problem arises. They allow others to perform their duties any way they see fit, without caring about the entailing results (Antonakis, 2001; Bass, 1990; Day and Antonakis, 2011).

Laissez-faire Leadership constitutes the negative component of the Multifactor Leadership model. Several empirical studies studying the behaviour of this kind of leader have demonstrated a strong negative correlation that exists between Laissezfaire Leadership and the other two types of Leadership (Antonakis, 2001; Day and Antonakis, 2011; Hinkin and Schriesheim, 2008; Tejeda et al., 2001).

From the above-mentioned literature review and the empirical studies, the following research hypothesis can be formed:

H2) Transformational and Transactional Leadership types are negatively correlated with Laissez-faire Leadership.

\subsection{Multifactor Leadership Theory and Leadership Outcomes}

Numerous surveys have demonstrated that leadership functions as a catalyst for optimising organizational results. Motivation, commitment, satisfaction, training and opportunities for learning, creativity, innovation, high efficiency and effectiveness of the employees and organizations rely crucially on the role and the practice of leadership power (Day and Antonakis, 2011; Horner, 1997; Van Seters and Field, 1990). For many of the elements of the impact of leadership on the organizations and on the employees, 
several researchers asserted that it would be difficult, if not impossible, to be accurately measured (Antonakis, 2001; Antonakis et al., 2003; Kuhnert and Lewis, 1987).

The Multifactor Leadership Questionnaire, introduced by Bass \& Avolio (1992; 1995), and the application of the Multifactor Leadership Theory, facilitates valid and reliable estimation of two key dependent dimensions/variables, referred to as "Leadership Outcomes", which are: the "Leadership Effectiveness" and the "Job Satisfaction". After the introduction of the questionnaire, the assessment of these dimensions in the empirical studies has been carried out through employee's image, thereby creating an anthropocentric estimation of these dimensions based on the perceptions of those who "follow" the instructions and suggestions of the leader (that means followercentric perceptions). For this reason, these dependent dimensions/variables (criteria) have been reported and used, respectively, with the appropriate titles of: "Followers' Perceived Leadership Effectiveness" and "Followers' Perceived Job Satisfaction" (Antonakis, 2001; Antonakis et al., 2003; Yadav and Misra, 2015; Yammarino and Bass, 1990).

The reference by Bass \& Avolio (1992; 1995) of these two dimensions, used as dependent variables, became popular because they were representing exactly the two classic dimensions of leadership's orientation: the "task/job oriented leadership" expressed through the variable of the "Followers' Perceived Leadership Effectiveness" and the "people/relations oriented leadership" expressed through the variable of the "Followers' Job Satisfaction". It is empirically accepted that leadership, in order to be assessed as "functional" for an organization, should exercise an dual and equal positive effect on both dependent variables mentioned above (Derue et al., 2011; Judge et al., 2004; Judge and Picollo, 2004).

Thus, within this context of Multifactor Leadership Theory, which emphasizes the balanced impact of leadership on both the task and the employee, it is empirically proved that when employees perceive their leadership as effective, they declare themselves satisfied with their job. Likewise, when employees express satisfaction with their job, they see their leadership as effective, precisely because effective leadership and job satisfaction are two interrelated facts of a successful organization (Antonakis, 2001; Antonakis et al., 2003; Day and Antonakis, 2011; Podsakoff et al., 1990; Podsakoff et al., 1996; Yadav and Misra, 2015).

From the above-mentioned literature review and the empirical studies, the following research hypothesis can be formed:

H3) “Followers' Perceived Leadership Effectiveness" is positively correlated with "Followers' Job Satisfaction".

\subsection{Modern Leadership Types and Leadership Outcomes}

In the light of the aforementioned model, the distinctive effect that Transformational Leadership exercises on both dependent variables mentioned above can be empirically measured and assessed in comparison with the respective effects that Transactional Leadership and Laissez-faire Leadership exercise on the same dependent variables. At the same time, the empirical verification of the different effects and responses that each leadership type exercises on both dependent variables (criteria) is used as strong evidence for the construct validity of the above-mentioned Multifactor Leadership Questionnaire. This fact highlights consequently the value of the corresponding 
Multifactor Leadership Theory as a tool for interpreting and assessing modern leadership and its influence on modern organizations (Antonakis, 2001; Antonakis and House, 2014; Yammarino and Bass, 1990).

Numerous surveys over the last three decades have empirically indicated the strong correlation of transformational leadership with all variables representing the full spectre of organizational outcomes. The transformational leadership is positively correlated with work commitment, with the development of organizational citizenship behaviour and job satisfaction (Antonakis, 2001; Armandi et al., 2003; Podsakoff et al., 1990; 1996). It has been proven that transformational leadership positively affects employees' motivation and empowerment, enhances their resolution and finally improves the organizations' and workers' efficiency and effectiveness (Antonakis and House, 2014; Podsakoff et al., 1990; 1996). Transformational leaders seem to be more efficient because they offer employees a sense of vision, a sense of attainable mission and a determination to fulfil higher expectations. They guide others to higher levels of performance and satisfaction because they can promote rationalization and intelligence, they can demonstrate personal attention to the employees and they can place the team interests above the individual ones (Antonakis, 2001; Antonakis et al., 2003; Khan et al., 2012).

Because of these positive effects that Transformational leadership has on the whole spectrum of what is called "Leadership Outcomes", the following research hypothesis can be put forward:

H4) Transformational Leadership is positively correlated with "Followers' Perceived Leadership Effectiveness" and “Followers' Job Satisfaction".
Despite the fact that leaders who have been assessed as high-performance leaders are classified by their subordinates more as transformational leaders and less as transactional leaders, these two types of leadership act complementary, raising each other's positive effect on the organizational variables. This fact constitutes the so-called "augmentation hypothesis" by Bass (1990), who refers to the increase of positive action of the transactional leadership when the effect of transformational leadership is added to this (Antonakis, 2001; Bass, 1990; Bass and Avolio, 1990).

This "hypothesis" by Bass is supported by a multitude of empirical studies that demonstrate the positive correlation between transactional leadership and "leadership outcomes", despite the fact that transactional leadership constitutes a more conservative leadership type in comparison with the transformational leadership (Antonakis, 2001; Antonakis et al., 2003; Avolio et al., 1999; Day and Antonakis, 2011; James and Ogbonna, 2013; Tejeda et al., 2001).

In accordance with these findings, the following research hypothesis can be put forward:

H5) Transactional Leadership is positively correlated with "Followers' Perceived Leadership Effectiveness" and "Followers' Job Satisfaction".

By overviewing a big number of empirical studies, it seems that transformational leadership, compared to the transactional leadership, is significantly correlated with increased levels of employees' motivation and empowerment and with higher employee satisfaction and efficiency (Bass, 1990; Bass and Avolio, 1990; Robbins and Judge, 2013). Other surveys have shown that transformational leaders are perceived by the followers to be the leaders with optimum performance 
and effectiveness, if compared to any other form of leadership. Furthermore, performance, effectiveness and satisfaction of the followers are identified at higher levels when their leadership is perceived to be transformational, rather than transactional (Bass, 1990; Robbins and Judge, 2013; Yammarino and Bass, 1990).

In the light of the aforementioned empirical findings, the following two research hypotheses can be drawn:

H6) Transformational Leadership has a stronger positive effect on "Followers" Perceived Leadership Effectiveness" than Transactional Leadership.

H7) Transformational Leadership has a stronger positive effect on "Followers' Job Satisfaction" "than Transactional Leadership.

In contrast, the empirical evidence shows that Laissez-faire Leadership has a clearly negative effect on the entire spectrum of organizational results (outcomes), such as effectiveness, motivation, commitment, engagement and employee job satisfaction (Bass, 1990; Bass and Avolio, 1990; Yammarino and Bass, 1990). The same results are derived from other studies which refer to the Laissez-faire Leadership and its implications when compared with the Transformational and Transactional leadership types (Antonakis, 2001; Day and Antonakis, 2011; Hinkin and Schriesheim, 2008; Tejeda et al., 2001).

Based on these findings, the following research hypothesis can be formulated:

H8) Laissez-faire Leadership is negatively correlated with "Followers' Perceived Leadership Effectiveness" and “Followers' Job Satisfaction”.

\section{RESEARCH METHODOLOGY}

The present survey is a case study which includes the four main types of research, i.e. the descriptive, the exploratory, the conclusive and the causal research. The Multifactor Leadership Questionnaire/MLQ was used as a research tool through the five-point Likert scale. Transformational, Transactional and Laissez-faire Leadership types were measured by the MLQ/6S form of Bass \& Avolio (1992), while the "Followers" Perceived Leadership Effectiveness" and the "Followers' Job Satisfaction" were measured by the MLQ/5X form of Bass \& Avolio (1995).

The survey was carried out in JanuaryFebruary 2016 and the research field was the public organization of Greek Public Procurement. Greek Public Procurement has 180 employees (including the managers), so 180 questionnaires were distributed by the researchers to all employees, hand-by-hand, thus covering the entire population of the employees in that organization. Out of this, 139 valid questionnaires were answered and collected (77.2\% response rate).

\subsection{Demographic Data}

Regarding the gender of the respondents, it was found that $42.45 \%$ (59) of them were male and $57.55 \%$ (80) were female. With regard to their age, it was found that $11.51 \%$ (16) of the respondents were aged between 25-34 years old, $48.92 \%$ (68) between 35-44 years old, $31.65 \%$ (44) between $45-54$ years old and $7.91 \%$ (11) were 55 and older. As far as the educational background is concerned, high school graduates constituted $13.67 \%$ (19) of the respondents, bachelor degree holders $30.94 \%$ (43), master's degree holders $48.92 \%$ (68) and PhD holders 6.47\% (9) of them. With regard to the overall working experience, the $20.9 \%$ of the respondents had a total length of service up to 11 years, $56.1 \%$ between $12-22$ years and the remaining $23 \%$ had an overall life of service 
between 23-34 years. We can note that in the sector of Greek Public Procurement, which was the target of our case study, the workforce is young with a high level of educational background and a high degree of scientific specialization, as more than half $(55.39 \%)$ of the respondents are holders of a postgraduate or a $\mathrm{PhD}$ degree.

\section{STATISTICAL ANALYSIS}

For the purpose of the statistical analysis we used SPSS 17.00 statistical package. We deployed descriptive statistics and we calculated the Cronbach's Alpha reliability indicator. For all the research hypotheses, after having made all the necessary diagnostic tests, we used Pearson's r-linear correlation coefficient and multiple regression analysis.

\subsection{Cronbach's Alpha Reliability Indicator}

Cronbach's Alpha reliability indicator is an evaluation measure of the reliability of sample responses and of the questionnaire structure. An increased value of that index (usually more than 0.7 ) is used as proof for the high reliability of the research. In our case, the Cronbach's Alpha index was measured on a very high level (0.923), (see Table 1).
Table 1: Cronbach's Alpha reliability indicator

\begin{tabular}{|c|c|c|c|}
\hline \multicolumn{4}{|c|}{ Case Processing Summary } \\
\hline & & $\mathrm{N}$ & $\%$ \\
\hline \multirow{3}{*}{ 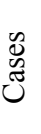 } & Valid & 139 & 100.0 \\
\hline & Excluded $^{\mathrm{a}}$ & 0 & 0.0 \\
\hline & Total & 139 & 100.0 \\
\hline \multicolumn{4}{|c|}{ Reliability Statistics } \\
\hline \multicolumn{2}{|c|}{ Cronbach's Alpha } & \multicolumn{2}{|c|}{$\mathrm{N}$ of Items } \\
\hline \multicolumn{2}{|c|}{0.923} & \multicolumn{2}{|c|}{27} \\
\hline
\end{tabular}

a. Listwise deletion based on all variables in the procedure

\subsection{Descriptive Statistical Data}

1) With regard to the independent variables expressed by the three leadership types, all these types have been detected at high levels. Transactional Leadership prevailed $($ mean $=3.24)$, followed by the Transformational Leadership $($ mean $=2.78)$ and the Laissez-faire Leadership (mean = 2.49), (see Figure 1).

2) Regarding the two dependent variables (criteria) expressed by the "Leadership Outcomes", namely: the "Followers' Perceived Leadership Effectiveness" and the "Followers' Job Satisfaction", both dimensions were also identified at high

\section{Figure 1: Means of Leadership Types}

\section{Leadership Types}

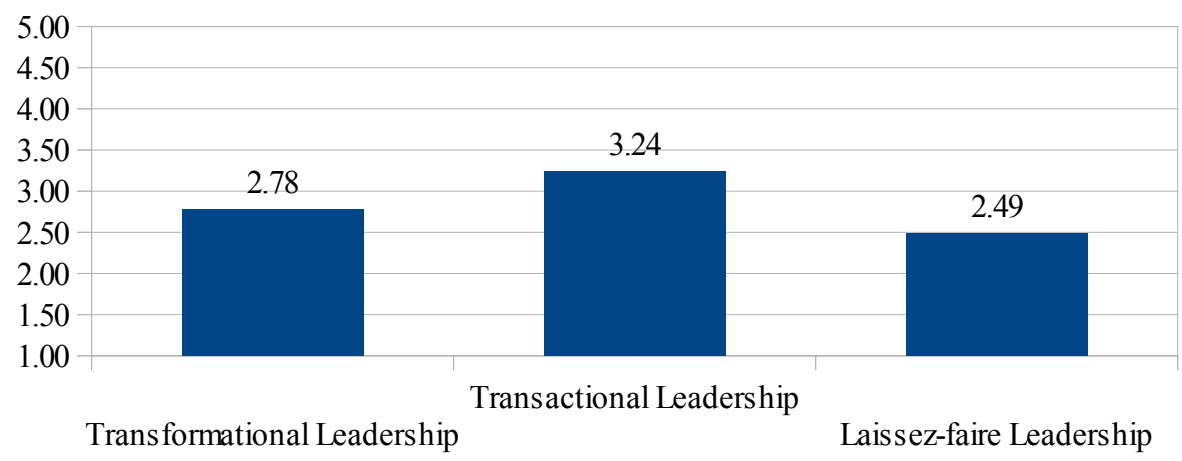




\section{Figure 2: Means of Leadership Outcomes}

\section{Leadership Outcomes}

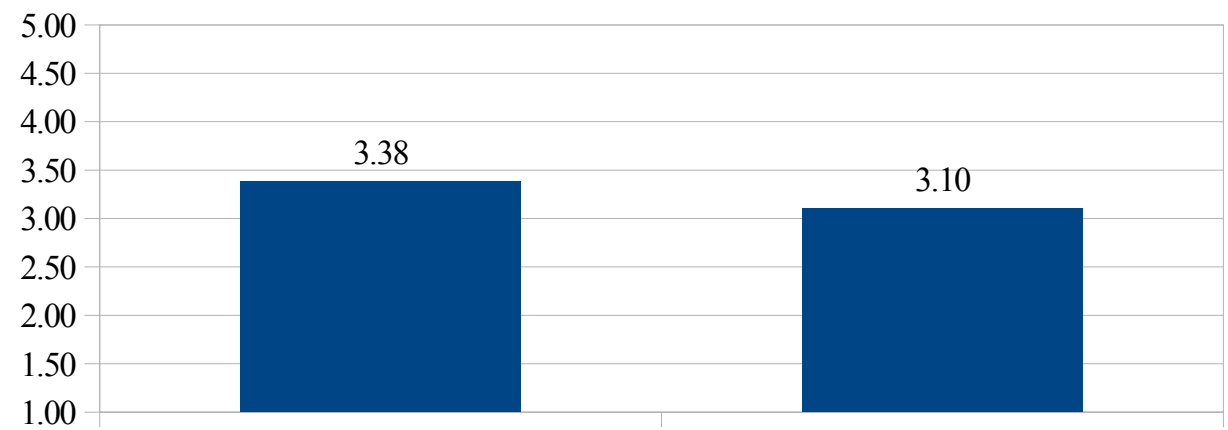

Followers' Job Satisfaction

Followers' Perceived Leadership Effectiveness

levels. "Followers' Perceived Leadership Effectiveness" prevailed (mean $=3.38$ ), followed by the "Followers' Job Satisfaction" $($ mean $=3.10)$, (see Figure 2$)$.

\subsection{Analysis of Research Hypotheses}

Implementing Pearson's linear correlation analysis on all research variables, we took the results described in Table 2, at a significance level of $\alpha=0.01$. Based on those, we can conclude that:

1) With regard to the correlations of Transformational Leadership with the Transactional Leadership, "Followers' Perceived Leadership Effectiveness" and "Followers' Job Satisfaction", the Pearson's r-linear correlation coefficients are posi-tive and statistically significant $(\mathrm{r}=0.750$, $\mathrm{r}=0.729$ and $\mathrm{r}=0.821$, respectively), indicating very strong positive correlations.

2) Regarding the correlations of TransactionalLeadershipwiththe "Followers' Perceived Leadership Effectiveness" and "Followers' Job Satisfaction", the Pearson's r-linear correlation coefficients are positive and statistically significant $(r=0.616$ and $\mathrm{r}=0.644$, respectively), indicating strong positive correlations.

3) With regard to the correlations of Transformational and Transactional Leadership types with Laissez-faire Leadership, the Pearson's r-linear correlation coefficients are negative and statistically significant $(r=-0.672$ and $r=-0.531$, respectively), indicating strong negative correlations.

4) Regarding the correlations of Laissezfaire Leadership with the "Followers' Perceived Leadership Effectiveness" and "Followers' Job Satisfaction", the Pearson's r-linear correlation coefficients are negative and statistically significant $(\mathrm{r}=-0.673$ and $\mathrm{r}=-0.641$, respectively) indicating strong negative correlations.

5) With regard to the correlation of 'Followers' Perceived Leadership Effectiveness" with "Followers' Job Satisfaction", the Pearson's r-linear correlation coefficient is positive and statistically significant $(\mathrm{r}=0.767)$, indicating a very strong positive correlation. 
Table 2: Pearson's Linear Correlation Coefficients

\begin{tabular}{|c|c|c|c|c|c|c|}
\hline & & 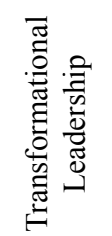 & 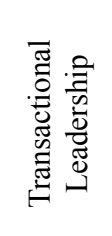 & 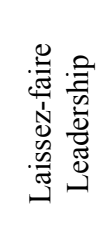 & 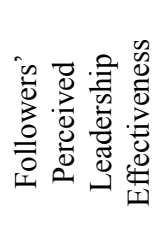 & 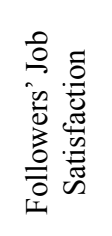 \\
\hline \multirow[t]{3}{*}{$\begin{array}{l}\text { Transformational } \\
\text { Leadership }\end{array}$} & $\begin{array}{c}\text { Pearson } \\
\text { Correlation }\end{array}$ & 1 & $0.750^{* *}$ & $-0.672^{* *}$ & $0.729^{* *}$ & $0.821^{* *}$ \\
\hline & Sig. (2-tailed) & & 0 & 0 & 0 & 0 \\
\hline & $\mathrm{N}$ & 139 & 139 & 139 & 139 & 139 \\
\hline \multirow[t]{3}{*}{$\begin{array}{l}\text { Transactional } \\
\text { Leadership }\end{array}$} & $\begin{array}{c}\text { Pearson } \\
\text { Correlation } \\
\end{array}$ & $0.750^{* *}$ & 1 & $-0.531^{* *}$ & $0.616^{* *}$ & $0.644^{* *}$ \\
\hline & Sig. (2-tailed) & 0 & & 0 & 0 & 0 \\
\hline & $\mathrm{N}$ & 139 & 139 & 139 & 139 & 139 \\
\hline \multirow[t]{3}{*}{$\begin{array}{l}\text { Laissez-faire } \\
\text { Leadership }\end{array}$} & $\begin{array}{l}\text { Pearson } \\
\text { Correlation }\end{array}$ & $-0.672^{* *}$ & $-0.531^{* *}$ & 1 & $-0.673^{* *}$ & $-0.641^{* *}$ \\
\hline & Sig. (2-tailed) & 0 & 0 & & 0 & 0 \\
\hline & $\mathrm{N}$ & 139 & 139 & 139 & 139 & 139 \\
\hline \multirow{3}{*}{$\begin{array}{c}\text { Followers' } \\
\text { Perceived } \\
\text { Leadership } \\
\text { Effectiveness }\end{array}$} & $\begin{array}{c}\text { Pearson } \\
\text { Correlation } \\
\end{array}$ & $0.729^{* *}$ & $0.616^{* *}$ & $-0.673^{* *}$ & 1 & $0.767^{* *}$ \\
\hline & Sig. (2-tailed) & 0 & 0 & 0 & & 0 \\
\hline & $\mathrm{N}$ & 139 & 139 & 139 & 139 & 139 \\
\hline \multirow[t]{3}{*}{$\begin{array}{l}\text { Followers' Job } \\
\text { Satisfaction }\end{array}$} & $\begin{array}{c}\text { Pearson } \\
\text { Correlation } \\
\end{array}$ & $0.821^{* *}$ & $0.644^{* *}$ & $-0.641^{* *}$ & $0.767^{* *}$ & 1 \\
\hline & Sig. (2-tailed) & 0 & 0 & 0 & 0 & \\
\hline & $\mathrm{N}$ & 139 & 139 & 139 & 139 & 139 \\
\hline
\end{tabular}

**Correlation is significant at the 0.01 level (2-tailed)

Subsequently, implementing multiple regression analysis, via the "enter" technique, we determined to what degree the three independent variables (Transformational, Transactional and Laissez-faire Leadership types) predict the two dependent variables ("Followers' Perceived Leadership Effectiveness" and "Followers' Job Satisfaction"):

A) Regarding the dependent variable "Followers' Perceived Leadership Effectiveness", the model seems to have a sufficient interpretative ability (Adjusted R Square $=0.592$ and Sig.<0.05). It proves the positive effect of the Transformational Leadership as statistically significant and very strong (Sig. $<0.05$ and Beta $=0.406$ ). At the same time, it demonstrates the negative effect of the Laissez-faire Leadership as statistically significant and strong enough (Sig. $<0.05 \&$ Beta $=-0.326$ ), considering simultaneously the weak positive effect of the Transactional Leadership as not statistically significant $($ Sig. $=0.094>0.05$ and Beta $=$ 0.139), (see Table 3).

B) Regarding the dependent variable "Followers' Job Satisfaction", the model seems to have sufficient interpretative 
Journal of Contemporary Management Issues

Table 3: Multiple Regression Analysis on

"Followers' Perceived Leadership Effectiveness"

\begin{tabular}{|c|c|c|c|c|c|c|}
\hline \multicolumn{7}{|c|}{ Model Summary ${ }^{b}$} \\
\hline Model & $\mathrm{R}$ & R Square & $\begin{array}{c}\text { Adjusted R } \\
\text { Square }\end{array}$ & $\begin{array}{l}\text { Std. Error of } \\
\text { the Estimate }\end{array}$ & \multicolumn{2}{|c|}{ Durbin-Watson } \\
\hline 1 & $0.775^{\mathrm{a}}$ & 0.601 & 0.592 & 0.51344 & \multicolumn{2}{|c|}{2.317} \\
\hline \multicolumn{7}{|c|}{ ANOVA $^{\mathrm{b}}$} \\
\hline \multicolumn{2}{|r|}{ Model } & $\begin{array}{l}\text { Sum of } \\
\text { Squares }\end{array}$ & $\mathrm{df}$ & Mean Square & $\mathrm{F}$ & Sig. \\
\hline \multirow[t]{3}{*}{1} & Regression & 53.574 & 3 & 17.858 & 67.742 & $0.000^{\mathrm{a}}$ \\
\hline & Residual & 35.589 & 135 & 0.264 & & \\
\hline & Total & 89.163 & 138 & & & \\
\hline \multicolumn{7}{|c|}{ Coefficients ${ }^{\mathrm{a}}$} \\
\hline \multirow{2}{*}{\multicolumn{2}{|c|}{$\begin{array}{l}\text { Model } \\
\text { B }\end{array}$}} & \multicolumn{2}{|c|}{$\begin{array}{l}\text { Unstandardized } \\
\text { Coefficients }\end{array}$} & $\begin{array}{l}\text { Standardized } \\
\text { Coefficients }\end{array}$ & \multirow[b]{2}{*}{$\mathrm{t}$} & \multirow[b]{2}{*}{ Sig. } \\
\hline & & Std. Error & Beta & & & \\
\hline \multirow[t]{4}{*}{1} & (Constant) & 2.535 & 0.351 & & 7.212 & 0.000 \\
\hline & $\begin{array}{l}\text { Transformational } \\
\text { Leadership }\end{array}$ & 0.367 & 0.085 & 0.406 & 4.309 & 0.000 \\
\hline & $\begin{array}{l}\text { Transactional } \\
\text { Leadership }\end{array}$ & 0.157 & 0.093 & 0.139 & 1.684 & 0.094 \\
\hline & $\begin{array}{l}\text { Laissez-faire } \\
\text { Leadership }\end{array}$ & -0.273 & 0.061 & -0.326 & -4.441 & 0.000 \\
\hline
\end{tabular}

ability (Adjusted R Square $=0.682$ and Sig. $<0.05)$. It proves the positive effect of the Transformational Leadership as statistically significant and very strong (Sig. $<0.05$ and Beta $=0.671)$. At the same time, it demonstrates the negative effect of the Laissez-faire Leadership as statistically significant (Sig. $=0.015<0.05$ and Beta $=-0.160$ ), considering simultaneously the weak posi-tive effect of the Transactional Leadership as not statistically significant $($ Sig. $=0.441>0.05$ and Beta $=0.056)$, (see Table 4).

Following the results of Pearson's linear correlation analysis, it can be concluded that:

1) The H1 hypothesis is fully verified, since Transformational Leadership is strongly positively correlated with Transactional Leadership ( $\mathrm{r}=0.750)$.

2) The H2 hypothesis is fully verified, since Transformational \& Transactional Leadership types are strongly negatively correlated with Laissez-faire Leadership ( $\mathrm{r}=$ - $0.672 \&-0.531$, respectively).

3) The H3 hypothesis is fully verified, since "Followers" Perceived Leadership Effectiveness" is strongly positively correlated with "Followers' Job Satisfaction" $(\mathrm{r}=0.767)$.

By combining the results of Pearson's linear correlation analysis with those of multiple regression analysis, through the "enter" technique, it can be concluded that: 
Table 4: Multiple Regression Analysis on "Followers' Job Satisfaction"

Model Summary ${ }^{b}$

\begin{tabular}{|c|c|c|c|c|c|c|}
\hline Model & $\mathrm{R}$ & R Square & $\begin{array}{l}\text { Adjusted } \\
\text { R Square }\end{array}$ & $\begin{array}{l}\text { Std. Error of } \\
\text { the Estimate }\end{array}$ & \multicolumn{2}{|c|}{ Durbin-Watson } \\
\hline 1 & $0.830^{\mathrm{a}}$ & 0.689 & 0.682 & 0.58501 & \multicolumn{2}{|c|}{1.893} \\
\hline \multicolumn{7}{|c|}{ ANOVA $^{b}$} \\
\hline \multicolumn{2}{|r|}{ Model } & $\begin{array}{l}\text { Sum of } \\
\text { Squares }\end{array}$ & $\mathrm{df}$ & Mean Square & $\mathrm{F}$ & Sig. \\
\hline \multirow[t]{3}{*}{1} & Regression & 102.535 & 3 & 34.178 & 99.868 & $0.000^{\mathrm{a}}$ \\
\hline & Residual & 46.202 & 135 & 0.342 & & \\
\hline & Total & 148.737 & 138 & & & \\
\hline \multicolumn{7}{|c|}{ Coefficients $^{\mathrm{a}}$} \\
\hline \multirow{2}{*}{\multicolumn{2}{|c|}{$\begin{array}{c}\text { Model } \\
\text { B }\end{array}$}} & \multicolumn{2}{|c|}{$\begin{array}{l}\text { Unstandardized } \\
\text { Coefficients }\end{array}$} & $\begin{array}{l}\text { Standardized } \\
\text { Coefficients }\end{array}$ & \multirow[b]{2}{*}{$\mathrm{t}$} & \multirow[b]{2}{*}{ Sig. } \\
\hline & & Std. Error & Beta & & & \\
\hline \multirow[t]{4}{*}{1} & (Constant) & 1.093 & 0.400 & & 2.729 & 0.007 \\
\hline & $\begin{array}{c}\text { Transformational } \\
\text { Leadership }\end{array}$ & 0.784 & 0.097 & 0.671 & 8.075 & 0.000 \\
\hline & $\begin{array}{l}\text { Transactional } \\
\text { Leadership }\end{array}$ & 0.082 & 0.106 & 0.056 & 0.773 & 0.441 \\
\hline & $\begin{array}{l}\text { Laissez-faire } \\
\text { Leadership }\end{array}$ & -0.173 & 0.070 & -0.160 & -2.474 & 0.015 \\
\hline
\end{tabular}

a. Predictors: (Constant), Laissez-faire Leadership, Transactional Leadership,

Transformational Leadership

b. Dependent Variable: Followers'Job Satisfaction

4) The H4 hypothesis is fully verified, since Transformational Leadership is strongly positively correlated with and predicts both "Followers' Perceived Leadership Effectiveness" and "Followers' Job Satisfaction" ( $\mathrm{r}=0.729 \& 0.821$, respectively and Beta $=0.406 \& 0.671$, respectively).

5) The H5 hypothesis is fully verified, since Transactional Leadership is strongly positively correlated with both "Followers' Perceived Leadership Effectiveness" and "Followers' Job Satisfaction" ( $r=0.616$ \& 0.644 , respectively), although it doesn't significantly predict these two dependent variables.

6) The H6 hypothesis is fully verified, since Transformational Leadership significantly predicts "Followers' Perceived Leadership Effectiveness" (Sig $<0.05 \quad \&$ Beta $=0.406$ ), while Transactional Leadership doesn't significantly predict this dependent variable $(\mathrm{Sig}=0.094>0.05)$.

7) The H7 hypothesis is fully verified, since Transformational Leadership significantly predicts "Followers' Job Satisfaction" $\quad(\mathrm{Sig}<0.05 \quad \& \quad$ Beta $=0.671)$, while Transactional Leadership doesn't significantly predict this dependent variable $(\mathrm{Sig}=0.441>0.05)$.

8) The H8 hypothesis is fully verified, since Laissez-faire Leadership is both strongly negatively correlated with and predicts both "Followers' Perceived Leadership Effectiveness" and "Followers' 
Job Satisfaction" (r=-0.673\&-0.641, respectively and Beta $=-0.326 \&-0.160$, respectively).

\section{CONCLUSIONS}

\subsection{Interpretation of Results}

The results of this research showed that the Transactional Leadership prevailed over the three types of leadership examined. It is obvious that in times of social crisis and economic downturn, the concept of charismatic, inspirational and transformational leadership is not adequately recognised among employees, a fact that is sufficiently supported by the literature review (Armandi et al., 2003; Day and Antonakis, 2011; James and Ogbonna, 2013). These same reasons, as well as the fact that we are talking about a country with strong collectivistic culture, can explain a strong presence of the Laissezfaire Leadership in our research. Greece is the country that culturally, socially and politically deviates enough from the common standards of western competitive societies. We are examining a country with rooted conservative aspects and a persistent bureaucratic concept and culture among its citizens and this is exactly the mentality and frame of mind that overwhelmingly prevails in the Greek public sector (Armandi et al., 2003; Day and Antonakis, 2011; Khan et al., 2012).

On the other hand, due to the fact that we examine a public organization with a young and highly skilled human capital, we can justify a strong presence of Transformational Leadership and, even more, a strong presence of the "Followers' Perceived Leadership Effectiveness" and the "Followers' Job Satisfaction" in our research. The results have fully confirmed the stronger positive correlation that Transformational Leadership has with "Followers' Perceived Leadership Effectiveness" and "Followers'
Job Satisfaction", in comparison with the Transactional Leadership. According to theory, these two dependent variables, constituting the "Leadership Outcomes", correspond to the two fundamental leadership orientations. Namely, the "Followers' Perceived Leadership Effectiveness" corresponds to the leadership orientation towards "task/ job" and the "Followers' Job Satisfaction" corresponds to the leadership orientation towards "people/relations". Furthermore, a very strong positive correlation that Transformational Leadership seems to have with these two fundamental leadership orientations, namely with "task/job" and "people/ relations" orientations, in comparison with any other leadership type, is fully verified. All these findings are in line with literature review, a fact that is also reinforced by the verification of the negative correlation that Laissez-faire Leadership is proved to have with these two dependent variables (criteria) mentioned above (Antonakis, 2001; Antonakis and House, 2014; Derue et al., 2011; Judge et al., 2004; Judge and Picollo, 2004).

Moreover, the research confirmed a positive link between Transformational and Transactional Leadership, as predicted in literature. Moreover, the same strong positive correlation between the two dependent variables, namely between the "Followers' Perceived Leadership Effectiveness" and the "Followers' Job Satisfaction", is also verified in accordance with the existing literature (Antonakis, 2001; Judge and Picollo, 2004; Tejeda et al., 2001). Similarly, the negative correlation between the Laissezfaire Leadership and the other two leadership types, respectively, is also verified to be in full accordance with theory (Hinkin and Schriesheim, 2008).

To sum up, all the above-mentioned findings verify unequivocally the distinct 
entity of the three leadership types developed by the Multifactor Leadership Theory. They also confirm the distinct effect which these three modern forms of leadership, as suggested by Bass, exercise onto the two "Leadership Outcomes" concerning the organizations and their employees. Eventually, these findings form a strong empirical evidence of the proper implementation of the Multifactor Leadership Theory and the validity of its respective questionnaire, at least for the organizations that constituted the target of our study, namely the sector of Greek Public Procurement (Antonakis, 2001; Antonakis et al., 2003; Kuhnert and Lewis, 1987; Yammarino and Bass, 1990).

Greek Public Procurement is a newly created public sector of the Greek Administration and belongs to the Ministry of Economics and Development while having the status of an Independent Authority. Its workforce includes a wide range of scientists, not just lawyers. It includes economists, engineers, chemists, computer experts, pharmacists, statisticians and so on. There is a wide range of economic issues and issues of a technical nature that fall within the jurisdiction of this organization. The rules governing its operation are the common and uniform rules that exist throughout the Greek public sector. With reference to its legal status, we cannot detect any specific rules or laws (or possible constraints) affecting the relationship between the leadership and employee satisfaction in these organizations.

On the other hand, supportive factors that are able to interpret the aforementioned research findings and the corresponding relation between the leadership and employee satisfaction in this organization seem to be its highly-skilled human capital and the very important mission that this sector performs. This mission includes the tackling of corruption in public administration, the realisation of the necessary reforms aiming at the country's development and the implementation of a new vision of modern organizational and administrative behaviour. Such a vision and leadership style that is able to implement this vision, are proving to be the real driving forces capable of leading organizations to optimum results and the well-being of their employees.

\subsection{Managerial Implications}

By having confirmed that the principles of Transformational Leadership have a strong positive relationship with the two dependent variables (criteria), which reflect the Leadership Outcomes on organizations and employees, we have essentially verified the strong positive orientation of that kind of leadership towards the "work task" and the "human relations". This encourages the practice and development of the proper transformational leadership qualities at any Greek public body, which can be achieved through adequate training of public sector managers, a continuous learning process and improvement of the employees' working and mental skills.

By having confirmed that Transactional Leadership also has a positive correlation with the two dependent variables mentioned above (but in a less powerful degree than Transformational Leadership), we have essentially verified the subsidiary role of such a leadership type in relation to the Transformational Leadership, as the so-called Bass' "augmentation hypothesis", (which concerns the augmentation of the positive action of the Transactional Leadership when the effect of the Transformational Leadership is added to this), predicts (Antonakis, 2001; Bass, 1990; Bass and Avolio, 1990).

On the other hand, the strong presence of Laissez-faire Leadership in our research shall be examined further, with special attention to the identification and correction 
of those elements leading to the development of such an indifferent and destructive behaviour by the leaders in Greek public organizations.

All the above findings highlight the need for a constant and strategic improvement in the management of public services, through a lifelong learning process, in order to adopt a culture of cooperation and meritocracy and a mentality of high effectiveness and efficiency expectations. The goal of such learning process and culture should be the elimination of reasons entailing the presence of the Laissez-faire Leadership, and the constant development and cultivation of the proper transformational leadership skills. The emergence of leaders with transformational characteristics, through a system of genuine meritocracy, with an organizational mentality of encouraging the reliable and charismatic officials in leadership positions, seems to be strongly correlated with positive organizational results and the well-being of the employees.

Thus, since this study defines a specific leadership model that can achieve the optimum organizational results (outcomes), it could be applicable to any public organization with leadership that possesses the appropriate transformational features which can inspire a vision materialized by a highly-skilled human capital dedicated to this vision, regardless of the specific framework of scientific activity they perform. More specifically, a common place for implementation of this study's model could be the public bodies that have the status of the Independent Authority, as Greek Public Procurement has.

The institution of the Independent Authority was introduced in Greece by the European Union. It provides common strategic planning and mission for all the organizations involved all over Europe. As a newly established institution, which seeks to establish uniform norms of public administration in all European countries, it prescribes the appropriate human resources staffing schemes and conditions that allow for modern and innovative models of leadership and organizational behaviour, such as the model in our study, to be implemented. Obviously, this concerns both Greece and the other European countries, especially those of Eastern Europe to which Greece also belongs.

\subsection{Limitations and Suggestions for Future Researchers}

The scientific rigor demonstrated by the researchers throughout this research did not preclude the existence of some restrictions therein. First of all, this research was a case study carried out in a highly specialized sector of the Greek public administration, which is the Sector of Public Procurement, so the number of the participants was relatively small, although it included the entire workforce, with a high response rate (77,2\%, since 139 employees replied out of 180). Therefore, the conclusions reached have possibly limited the possibility for generalization and implementation to larger sectors or different working environments. Furthermore, current research took place in a public organization amidst an unprecedented economic and social crisis in Greek society, entailing many restrictions among employees with regards to openly sharing their opinions.

It could be suggested that future research focus on larger public organizations, through random sampling, expanding further on the leadership concept and its effect on the organizational outcomes. It is worth extending the research to include the private sector organizations, so that the future researchers are able to carry out comparative studies between the results concluded from public organizations and those derived from the private sector. 


\section{REFERENCES}

1. Antonakis, J., 2001. "The validity of the tranformational, transactional and laissez-faire leadership model as measured by the Multifactor Leadership Questionnaire (MLQ$5 X)$ ", Unpublished PhD thesis, Walden University ScholarWorks, Minneapolis, Minnesota, USA.

2. Antonakis, J., Avolio, B. and Sivasubramaniam, N., 2003. "Context and leadership: an examination of the nine-factor full-range leadership theory using the Multifactor Leadership Questionnaire", The Leadership Quarterly, Vol. 14 No. 3, pp. 261-295.

3. Antonakis, J. and House, R., 2014. "Instrumental leadership: Measurement and extension of transformationaltransactional leadership theory", The Leadership Quarterly, Vol. 25 No. 4, pp. 746-771.

4. Armandi, B., Oppedisano, J. and Sherman, H., 2003. "Leadership theory and practice: a case in point", Management Decision, Vol. 41 No. 10, pp. 1076-1088.

5. Avolio, B., 2007. "Promoting more integrative strategies for Leadership theorybulding", American Psychologist, Vol. 62 No. 1, pp. 25-33.

6. Avolio, B., Bass, B. and Jung, D., 1999. "Re-examining the componets of transformational and transactional leadership using the Multifactor Leadership Questionnaire", Journal of Occupational and Organizational Psychology, Vol. 72 No. 4, pp. 441-462.

7. Bass, B., 1990. "From transactional to transformational leadership: learning to share the vision", Organizational Dynamics, Vol. 18 No. 3, pp. 19-32.

8. Bass, B. and Avolio, B., 1990. "Developing the transformational leadership: 1992 and beyond", Journal of
European Industrial Training, Vol. 14 No. 5, pp. 21-27.

9. Bass, B. and Avolio, B., 1992. "Multifactor leadership questionnaireShort Form 6S", Binghamton, NY: Center for Leadership Studies.

10. Bass, B. and Avolio, B., 1995. "The Multifactor Leadership Questionnaire”, Palo Alto, CA: Mind Garden, Inc., USA.

11. Day, D. and Antonakis, J., 2011. "The nature of leadership", Sage Publications, Inc., Thousand Oaks, CA, USA.

12. Derue, D., Nahrgang, J., Wellman, N. and Humphrey, S., 2011. "Trait and behavioral theories of leadership: An integration and meta-analytic test of their relative validity", Personnel Psychology, Vol. 64 No. 1, pp. 7-52.

13. Hinkin, T. and Schriesheim, C., 2008. "A theoretical and empirical examination of the transactional and non-leadership dimensions of the Multifactor Leadership Questionnaire (MLQ)", The Leadership Quarterly, Vol. 19 No. 5, pp. 501-513.

14. Horner, M., 1997. "Leadership theory: past, present and future", Team Performance Management: An International Jourmal, Vol. 3 No. 4, pp. 270-287.

15. House, R., 1996. "Path-goal theory of Leadership: Lessons, legacy and a reformulated theory", Leadership Quarterly, Vol. 7 No. 3, pp. 323-352.

16. James, O. and Ogbonna, I., 2013. "Transformational vs. Transactional leadership theories: Evidence in literature", International Review of Management and Business Research, Vol. 2 No. 2, pp. 355-361.

17. Judge, T. and Piccolo, R., 2004. "Transformational and Transactional Leadership: A meta-analytic test of their relative validity, Journal of Applied 
Psychology, Vol. 89 No. 5, pp. 755-768.

18. Judge, T., Piccolo, R. and Ilies, R., 2004.

"The forgotten ones? The validity of consideration and initiating structure in leadership research", Journal of Applied Psychology, Vol. 89 No. 1, pp. 36-51.

19. Khan, M., Aslam, N. and Riaz, M., 2012. "Leadership styles as predictors of innovative work behavior", Pakistan Journal of Social and Clinical Psychology, Vol. 10 No. 1, pp. 17-22.

20. Kuhnert, K. and Lewis, P., 1987. "Transactional and Transformational leadership: a constructive/developmental analysis", Academy of Management Review, Vol. 12 No. 4, pp. 648-657.

21. Podsakoff, P., MacKenzie, S., Moorman, R. and Fetter, R., 1990. "Transformational leader behaviors and their effects on followers' trust in leader, satisfaction and organizational citizenship behaviors", Leadership Quarterly, Vol. 1 No. 2, pp. 107-142.

22. Podsakoff, P., MacKenzie, S. and Bommer, W., 1996. "Transformational leader behaviors and substitutes for leadership as determinants of employee satisfaction, commitment, trust and organizational citizenship behaviors", Journal of Management, Vol. 22 No. 2, pp. 259-298.
23. Robbins, S. and Judge, T., 2013. Organizational Behavior, $15^{\text {th }}$ Edition, Pearson Education, Inc., Prentice Hall, New Jersey, USA.

24. Silva, A., 2015. "An integrated Leadership theory", Journal of Perspectives in Organizational Behavior, Management and Leadership, Vol. 1 No. 1, pp. 5-9.

25. Tejeda, M., Scandura, T. and Pillai, R., 2001. "The MLQ revisited: Psychometric properties and recommendations", The Leadership Quarterly, Vol. 12 No.1, pp. 31-52.

26. Van Seters, D. and Field, R., 1990. "The evolution of leadership theory", Journal of Organizational Change Management, Vol. 3 No. 3, pp. 29-45.

27. Yadav, V. and Misra, N., 2015. "Effect of perceived leadership and organizational commitment on turnover intention of semi-skilled workers in small scale industries", International Journal of Research in Business Studies and Management, Vol. 2 No. 8, pp. 8-16.

28. Yammarino, F. and Bass, B., 1990. "Transformational leadership and multiple levels of analysis", Human Relations, Vol. 43 No. 10, pp. 975-995. 


\section{MODERNO VOĐENJE I NJEGOVI ISHODI: SLUČAJ GRČKOG JAVNOG SEKTORA}

\section{SAŽETAK}

Cilj ovog istraživanje je iskazivanje razlika modernih tipova vođenja, uz pomoć multifaktorske teorije vođenja, odnosno identificiranja oblika vođenja, zasnovanih na transformacijskom, transakcijskom i laissez-faire tipu vođenja. Ciljevi istraživanja fokusiraju se na posebne efekte navedenih tipova vođenja (prema Bassu): kako na ishode vođenja, kako ih percipiraju sljedbenici (zaposlenici) - promatrane kroz efektivnost vođenja, percipiranu od strane sljedbenika, tako i na zadovoljstvo sljedbenika poslom.
Istraživanje je provedeno studijom slučaja u grčkom sektoru javne nabave, korištenjem upitnika Multifactor Leadership Questionnaire (MLQ). Transformacijsko vođenje snažno i pozitivno utječe na učinkovitost vođenja, percipirano od strane sljedbenika, kao i na razinu, u kojoj su sljedbenici zadovoljni s poslom. Pozitivni utjecaj transakcijskog vođenja na navedene kriterije je slabiji, negoli u prethodnom slučaju, dok je utjecaj laissez-faire vođenja negativan. Dobiveni se rezultati mogu primijeniti u organizacijama javnog sektora s visokim standardima radnih postignuća. 
